\title{
Protective Effect of Summer Savory (Satureja Hortensis) Essential Oil on Some Growth, Biochemical, Immune Serum, Mucosal Immune System and Antioxidant Parameters of Common Carp (Cyprinus Carpio) Exposed to Pretilachlor Herbicide
}

\author{
Abduladheem Turki Jalil \\ Islamic University \\ Walid Kamal Abdelbasset \\ Prince Sattam bin Abdulaziz University College of Medicine \\ Rustem Adamovich Shichiyakh \\ Kuban State Agrarian University \\ Gunawan Widjaja ( $\nabla$ gunawan1widjaja@gmail.com ) \\ Universitas Krisnadwipayana \\ Usama S. Altimari \\ Al Nisour University College: Al-Nisour University College \\ Surendar Aravindhan \\ Saveetha University Saveetha Dental College \\ Hayfaa Attia Thijail \\ Thi Qar University \\ Yasser Fakri Mustafa \\ University of Mosul \\ Saeid Shahbazi Naserabad \\ University of Tehran
}

\section{Research Article}

Keywords: Plant medicine, Satureja hortensis, Herbicide, Growth, Immunity, Common carp.

Posted Date: January 18th, 2022

DOI: https://doi.org/10.21203/rs.3.rs-1198387/v1

License: (c) This work is licensed under a Creative Commons Attribution 4.0 International License. Read Full License 


\section{Abstract}

The main objective of the present study is to investigate the protective effect of summer savory (Satureja hortensis) essential oil (SEO) on growth and survival parameters, liver enzymes, immune serum, mucosal immune system and biochemical profiles of common carp (Cyprinus carpio) exposed to pretilachlor herbicide. Fish with the mean initial weight of $(25.35 \pm 0.13 \mathrm{~g})$ assigned to six treatment groups $\left(T_{1}\right.$ : control treatment; $T_{2}$ : low concentration of toxin ( $25 \%$ $\mathrm{LC}_{50}$ pretilachlor herbicide); $\mathrm{T}_{3}$ : high concentration of toxin ( $50 \% \mathrm{LC}_{50}$ pretilachlor herbicide); $\mathrm{T}_{4}: 1 \% \mathrm{SEO} ; \mathrm{T}_{5}$ : Iow concentration of toxin $+1 \%$ SEO; and $T_{6}$ : high concentration of toxin $+1 \%$ SEO) were fed with experimental diets containing 1\% SEO for 21 days. The results showed that the SEO-containing treatments significantly increased survival rate compared to the control group $(\mathrm{P}<0.05)$. The highest final weight, specific growth rate and feed conversion ratio were observed in $T_{4}$ treatment $(P<0.05)$. Glucose levels decreased in the SEO-containing treatments, and the treatment $T_{4}$ showed a statistical difference with the control group $(\mathrm{P}<0.05)$; in treatments exposed to pretilachlor herbicide, the glucose levels increased compared to the control and there was a significant difference $(P<0.05)$. The highest total protein content was observed in the treatment $T_{4}$ containing SEO, which was significantly different from the control

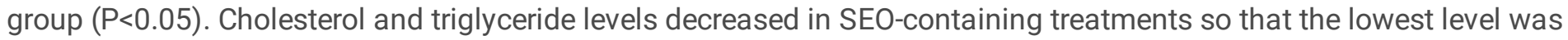
found in the treatment $\mathrm{T}_{4}(\mathrm{P}<0.05)$. Alternative complement pathway activity $\left(\mathrm{ACH}_{50}\right)$ showed an increasing trend in SEOcontaining treatments so that the highest level was seen in the treatment $T_{4}(P<0.05)$. The results revealed that the activity levels of antioxidant enzymes of superoxide dismutase (SOD) and glutathione peroxidase (GPX) increased in the SEO-containing treatments compared to the control group and the treatments containing pretilachlor herbicide, and malondialdehyde (MDA) had the lowest content in the treatment $T_{4}$, which showed a significant difference with the control group $(P<0.05)$. The activity of liver enzymes, which indicates tissue damage, showed the lowest level in the treatment $T_{4}$, which was statistically different from other treatments $(P<0.05)$. To conclude, the findings of this study highlighted that the use of SEO in fish exposed to pretilachlor herbicide improves digestion and absorption of nutrients, promotes better growth, strengthens the immune system of fish and exerts a protective effect for the common carp species.

\section{Introduction}

It is widely accepted that the use of herbicides has increased significantly the crop yield. However, following the increasing use of herbicides in modern agriculture, a large proportion of these herbicides are accumulated in surface waters through surface runoff, leaching and drift, and is associated with environmental hazards for aquatic organisms and human health (Jiang et al. 2016; Suchiang 2021). Changes in the chemical composition of aquatic environments and exposure of fish to pesticides result in behavioral disorders, physiological disorders, histopathological injuries, hematological alterations, biochemical changes, suppression of the immune system, hormonal disorders, and thus effects on fish growth, reproduction, and behavior (Gilliom 2007; Solomon et al. 2008; Xu et al. 2011; Srivastava et al. 2016; Soni and Verma 2018; Kumari 2020; Suchiang 2021). In addition, prolonged exposure to pesticides causes death, physical and morphological changes in fish (Yogesh et al. 2009). Therefore, in the present era, it is inevitable to use pesticides in agriculture, although their impact on non-target organisms is greater than their impact on the pests of interest (Suchiang 2021).

Chloroacetamides are among the most widely used herbicides for pre-emergence control of undesirable weeds and broadleaf weeds in corn, cotton, soybeans and many other crops (Jiang et al. 2016; Soni and Verma 2018). Among these, one of the most widely used herbicides is pretilachlor with the chemical formula of 2-chloro-2',6' -diethyl-N-(2 propoxyethyl) acetanilide (Partha et al. 2009; Jiang et al. 2016). The pretilachlor is exploited for rapid control during the unexpected growth of annual grasses and broadleaf weeds in rice fields (Jiang et al. 2016), which will naturally enter surface waters (Hladik et al. 2008). 
The pollutants weakened the immune system of fish and increased the susceptibility of fish to pathogens (AbdelTawwab et al. 2010; Abdel-Latif et al. 2020; Yousefi et al. 2021b). Toxins and pesticides are the main causes of poisoning in fish. Of the thousands of chemicals released, pesticides cause high mortality, even at very low concentrations (Sanchez-fortun and Barahona 2005).

Plant essential oils, with their abundant antioxidant and antimicrobial properties, can exert positive effects on growth performance, resistance to environmental stress, infectious diseases, stimulation of nonspecific immune system and some blood parameters in livestock, poultry and aquaculture (Dugenci et al. 2003; Fallahi Kapoorchali et al. 2009; Awad and Awaad 2017; Abdel-Latif et al. 2020; Mohammadi et al. 2020; Abdel-Tawwab and El-Araby 2021; Ghafarifarsani et al. 2021a; Yousefi et al. 2021a; Yousefi et al. 2021b; Raissy et al. 2022). Improving the flavor of the diet by plant compounds stimulate growth, cause weight gain, stimulate the secretion of pancreatic enzymes, help digest and absorb important nutrients (Frankic et al. 2009; Abdel-Tawwab et al. 2010).

The important role of the immune system in maintaining the health of aquatic animals and ensuring their survival and proper growth during the breeding period, has led researchers to use a variety of chemical and natural compounds that stimulate and strengthen the immune system (Galina et al. 2009; Pandey et al. 2012; Reverter et al. 2014; Myszka et al. 2019; Alagawany et al. 2021). Numerous studies have shown that various plant extracts increase immunity, including increased serum complement levels, plasma protein content, serum globulin and lysozyme, as well as growth (Greathead 2003; Wu et al. 2007; Windisch et al. 2008; Alishahi et al. 2011; Harikrishnan et al. 2011; Abdel-Tawwab and El-Araby 2021; Ghafarifarsani et al. 2021a,b; Alagawany et al. 2021; Ghafarifarsani et al. 2022; Raissy et al. 2022). Therefore, food additives can affect the physiology of fish, including increasing immune responses and health status, improving growth rate, as well as protecting fish from harmful factors (Hajirezaee et al. 2019). Medicinal plants, including summer savory (Satureja hortensis), which contain substances that stimulate growth and appetite, as well as boost the immune system and many other beneficial properties, are used as a suitable alternative to chemical drugs (Akbarzadeh, 2003). The genus Satureja belongs to the family Lamiaceae (Hernández-Contreras and Hernández 2020), which is widely used in food preparation and has a special role in the pharmaceutical industry and traditional medicine (Taherian et al. 2019) and is rich in thymol and carvacrol (Hernández-Contreras and Hernández 2020). Other plants in this family include Thymus vulgaris, Origanum majorana and Origanum vulgare, which are known to have growth-promoting, antioxidant and immune-boosting effects in fish (Yousefi et al. 2021b).

Fish, like many other vertebrates, have defense mechanisms to counteract the harmful effects of reactive oxygen species (ROS) caused by the metabolism of various chemicals or xenobiotics. The first line of defense includes low molecular weight antioxidants (such as glutathione and vitamins $\mathrm{C}$ and $\mathrm{E}$ ), and the secondary defense mechanism includes antioxidant enzymes such as superoxide dismutase (SOD), glutathione peroxidase (GSH-Px), catalase (CAT) and glutathione S-transferase (GST) (Puangkaew et al. 2005; Blahová et al. 2013). Recent studies have shown that the toxicity of pesticides in fish may be associated with increased ROS production, which causes oxidative damage to biological systems (Yonar and Sakin 2011). The oxidative stress refers to an imbalance between the production and neutralization of ROS by antioxidant mechanisms within an organism (Puangkaew et al. 2005; Valavanidis et al. 2006); specification of antioxidant enzymes can help identify and highlight this stress.

Vertebrate immune systems, including the immune system of osteichthyes, react with certain sensitivities to xenobiotic exposure. In addition, many fish diseases are related to the quality of the environment and various environmental pollutants have immunotoxic potential (Betoulle et al. 2000). Because fish change their metabolic function to adapt to new conditions during stress, analysis of blood biochemical parameters can reveal the physiological state and health of fish (Agrahari et al. 2007; Silambarasan and Hemalatha 2015).

One of the most important components of the innate immune system in fish is the mucosal immune system. Fish epidermal mucus contains a variety of biologically active agents such as lysosomes, flavoenzymes, immunoglobulins

Page 3/19 
and antimicrobial peptides. Mucous secretions by trapping high concentrations of toxins prevent their introduction into the fish body (Magnadottir 2006; Subramanian et al. 2007). Therefore, studying the parameters of the mucosal immune system will help us to understand the biological conditions of fish and reduce the immune function of fish due to stress caused by pollutants (Magnadottir 2006).

Common carp (Cyprinus carpio) is an economically important species in the world, accounting for $71.9 \%$ of freshwater production, and its production has increased from 2.9 million tons in 2008 to 4.1 million tons in 2017, with an increase of almost 30\% (Mohammadi et al. 2020).

Despite significant progress, the aquaculture sector is always associated with challenges such as changes in water quality and pollution by pesticides, as well as nutritional problems. In addition, the importance of common carp and increasing the resistance and improving the immune system of this fish against environmental factors, as well as in order to increase growth and survival, it seems necessary to use some additives. Accordingly, the present study aimed to investigate the protective effect of summer savory (Satureja hortensis) essential oil (SEO) on growth and survival parameters, liver enzymes, immune serum, mucosal immune system and biochemical profiles of common carp (Cyprinus carpio) exposed to pretilachlor herbicide.

\section{Materials And Methods}

\subsection{Preparation of herbal extract}

The SEO was purchased ready-made from Tabib Daru Company (Kashan-Iran). The chemical composition of SEO was determined by Gas chromatography-Mass Spectrometry (GC-MS, model-Shimadzu-9A), the results of which confirmed the presence of Carvacrol (29.6\%), gamma-Terpinene (26.3\%), Para-Cymene (14.1\%), alpha-Terpinene (9.7\%), Myrcene (2.5\%), alpha-Pinene (2.1\%) and alpha-thujene (1.9\%).

The basic diet components used (Faradaneh Company, Iran), respectively, including fish meal (10\%), soybean meal (23\%), meat meal (21\%), wheat meal (40.8\%), fish oil (1\%), soybean oil (1\%), lysin $(0.7 \%)$, methionine $(0.5 \%)$, vitamin mix (1\%) and mineral mix (1\%); crude protein (37\%), crude lipid (6\%), crude fiber (6\%), digestible phosphorus (1.25\%) and moisture (7\%) were thoroughly mixed while adding SEO and water gradually (Ghafarifarsani et al. 2022). The resulting mixture was pelletized using a meat grinder and dried in a dark place for 24 hours.

\subsection{Experimental design}

Carp were purchased from the carp sales center in Hashtgerd (Karaj, Iran) and transferred to Mohammad Shahr (Karaj, Iran) for further testing. After isothermalization and adaptation of the juveniles to the new conditions and feeding on a basic diet in the form of pellets for two weeks, the fish were examined to ensure the health and natural structure of the body. After the initial bioassay, 360 completely healthy fish with an initial weight of $25.35 \pm 0.13 \mathrm{~g}$ were kept in 18 fiberglass tanks (20 fish per tank) for 21 days in a completely randomized design six treatment groups ( $T_{1}$ : control treatment; $\mathrm{T}_{2}$ : low concentration of toxin ( $25 \% \mathrm{LC}_{50}$ pretilachlor herbicide); $\mathrm{T}_{3}$ : high concentration of toxin $\left(50 \% \mathrm{LC}_{50}\right.$ pretilachlor herbicide); $\mathrm{T}_{4}: 1 \%$ SEO; $\mathrm{T}_{5}$ : low concentration of toxin $+1 \% \mathrm{SEO}$; and $\mathrm{T}_{6}$ : high concentration of toxin $+1 \%$ SEO). The fish were fed with basic food ( $2 \%$ of fish body weight) twice.

During the experimental period, the physicochemical factors of reservoir water were measured daily, so that the water temperature was measured by a thermometer $\left(22.2 \pm 0.7^{\circ} \mathrm{C}\right)$, the $\mathrm{pH}$ value by a portable $\mathrm{pH}$ meter $(7.6 \pm 0.2)$, and dissolved oxygen by a digital oxygen meter $(6.1 \pm 3 \mathrm{mg} / \mathrm{L})$.

The fish were kept in a 12/12 h light/dark cycle. To maintain water quality and to remove waste products, uneaten foods were siphoned and water was renewed daily. 


\subsection{Determination of lethal concentration $\left(\mathrm{LC}_{50}\right)$ values of pretilachlor herbicide}

In order to perform the main experiment, there was a need to obtain knowledge of the lethal range and acute concentration of the contaminant on the fish species to determine the subacute test doses. To determine the $L_{50}$ value for pretilachlor herbicide on common carp using the standard method of O.E.C.D (1994), 180 fish were selected as resident in six treatment groups of 10 , each in triplicate $(0,0.75,1,2,4$ and $6 \mathrm{mg} / \mathrm{L})$ and placed in 60 -liter tanks. The lethal concentration test lasted 96 hours and the number of deaths was counted at 24, 48, 72, and 96 hours and recorded. The number of deaths from the time of pollutant induction till 24 hours was considered as the first day mortality, the number of deaths from pollutant induction till 48 hours as the second day mortality, the number of deaths from pollutant induction till 72 hours as the third day mortality and the number of deaths from pollutant induction till 96 hours as the fourth day mortality (Hedayati et al. 2015; Shahbazi Naserabad 2017). The physicochemical properties of the water were controlled, and all conditions were maintained the same during the test period so that different doses of contamination were the only variable factor. Finally, the number of fish lost was recorded after 24, 48, 72 and 96 hours. Then, based on the statistical method of Probit program version 0.16 , the values of $\mathrm{LC}_{10}, \mathrm{LC}_{30}, \mathrm{LC}_{50}, \mathrm{LC}_{70}$ and $\mathrm{LC}_{90}$ were calculated for carp (Table 1).

Table 1

Lethal Concentrations $\left(\mathrm{LC}_{10-90}\right)$ of Pretilachlor depending on time (24-96h) for Cyprinus carpio (mean \pm SE)

\begin{tabular}{|lllll|}
\hline Point & \multicolumn{4}{l}{ Concentration $(\mathrm{mg} / \mathrm{l})(95 \%$ of confidence limits $)$} \\
\cline { 2 - 5 } & $24 \mathrm{~h}$ & $48 \mathrm{~h}$ & $72 \mathrm{~h}$ & $96 \mathrm{~h}$ \\
\hline $\mathrm{LC}_{10}$ & $2.78 \pm 0.12$ & $2.29 \pm 0.1$ & $2.04 \pm 0.1$ & $1.61 \pm 0.09$ \\
\hline $\mathrm{LC}_{30}$ & $3.68 \pm 0.12$ & $3.28 \pm 0.1$ & $3.01 \pm 0.1$ & $2.58 \pm 0.09$ \\
\hline $\mathrm{LC}_{50}$ & $4.30 \pm 0.12$ & $3.96 \pm 0.1$ & $3.68 \pm 0.1$ & $3.26 \pm 0.09$ \\
\hline $\mathrm{LC}_{70}$ & $4.92 \pm 0.12$ & $4.65 \pm 0.1$ & $4.35 \pm 0.1$ & $3.93 \pm 0.09$ \\
\hline $\mathrm{LC}_{90}$ & $5.82 \pm 0.12$ & $5.63 \pm 0.1$ & $5.32 \pm 0.1$ & $4.90 \pm 0.09$ \\
\hline
\end{tabular}

\subsection{Sampling procedure}

As mentioned, after 21 days of diet feeding and exposure to pretilachlor herbicide, the fish were bioassayed to assess growth performance. Serum biochemical, antioxidant and immune responses were also measured and calculated. To this end, six fish in each treatment were randomly selected to collect blood samples and anesthetized by clove powder (150 ppm) (Ghafarifarsani et al. 2021a).

Thus, the blood samples were taken from the caudal vein of fish using a sterilized 2-mL syringe. To collect serum to measure biochemical, immune, and antioxidant parameters, the blood samples were immediately transferred to tubes and allowed to coagulate at room temperature for $30 \mathrm{~min}$. Skin mucus samples were also collected by an indirect method (Ross et al. 2000; Ghafarifarsani et al. 2021a).

\subsection{Growth performance}

After feeding the treatments with the specified feed for 21 days, at the end of the experiment, the number of fish losses, if any, during the study, the consumed feed and the final weight of the fish were recorded. Then, growth indices were measured using the following equations: 
Weight gain $(W G)(g)$ = initial weight - final weight

Specific growth rate $(S G R)(\% / d)=(\{$ In final wt $(g)-$ In initial wt $(g)\} /$ days $) \times 100$

Feed conversion rate $(\mathrm{FCR})=$ total feed given $(\mathrm{g}) /$ weight gain $(\mathrm{g})$

Survival rate $(\mathrm{SR})(\%)=($ final numbers $/$ initial numbers $) \times 100$

\subsection{Measurement of biochemical compounds}

At the end of the experimental period, six fish were randomly sampled from each experimental tank to analyze and determine biochemical indicators. The biochemical parameters included total protein (TP), albumin (ALB), glucose (GLU), cortisol (CORT), triglyceride (TRIG), cholesterol (CHOL) and lactate dehydrogenase (LDH). After drawing blood from the caudal vein of the fish, blood was poured into a 2-mL eppendorf tube and after centrifugation with a microcentrifuge at a speed of $1000 \times \mathrm{g}$ at $4^{\circ} \mathrm{C}$ for 5 minutes to obtain the serum. The obtained serum was stored in a freezer at $-20^{\circ} \mathrm{C}$ until testing biochemical parameters. The values of these parameters were measured by an automated biochemical analyzer (Roche Hitachi 911 Chemistry Analyzer, Japan). The serum cortisol (CORT) levels were measured by a commercial ELISA kit (ZellBio, Germany). Finally, the serum globulin (GLO) was also calculated from the difference between total serum protein and albumin (Naiel et al. 2021).

\subsection{Measurement of liver enzymes and antioxidants in blood serum}

Antioxidant enzymes, including glutathione peroxidase (GPx), superoxide dismutase (SOD), catalase (CAT), and malondialdehyde (MDA), were determined using a commercial kit (Berlin, Germany $₫$ ®Zellbio) according to the manufacturer's protocol (Hoseinifar et al. 2020; Raissy et al. 2022).

The activity levels of liver enzymes including aspartate aminotransferase (AST), alkaline phosphatase (ALP) and alanine aminotransferase (ALT) were measured by spectrophotometry using commercial kits (Pars Azmun Co., Iran) (Hoseini et al. 2012, 2018).

\subsection{Assessment of parameters related to the mucosal immune system}

In order to collect mucus samples, six fish were randomly sampled from each tank, anesthetized by clove powder separately, placed in polyethylene zipper bags containing $10 \mathrm{~mL}$ of $50 \mathrm{mM}$ sodium chloride for two minutes and then removed from the bags. The collected mucus samples were transferred to sterile $15-\mathrm{mL}$ centrifuge tubes and centrifuged for 10 minutes at $4^{\circ} \mathrm{C}$ and $1500 \mathrm{~g}$; the resulting supernatant was transferred to a 1.5 -cc microtube for further analysis (Vali et al. 2020).

Immunological parameters were analyzed in samples of serum and mucus by using conventional techniques. According to the slightly modified method of Demers and Bayne (1997), lysozyme activity was determined in serum and mucus samples. In brief, $0.2 \mathrm{mg} / \mathrm{ml}$ of the bacterium (Micrococcus luteus) suspension was prepared with the sodium phosphate buffer $(0.05 \mathrm{M}, \mathrm{pH}$ 6.2). Sixty $\mu \mathrm{L}$ of the sample was mixed with the bacterium suspension $(2 \mathrm{ml})$ and incubated for three minutes, then the absorbance was read after 3 minutes. One unit of lysozyme was considered a decrease of 0.001 per min in absorbance. Alternative complement pathway hemolytic activity $\left(\mathrm{ACH}_{50}\right)$ was measured in samples of serum and mucus through the method developed by Ortuno et al. (2000), which is based on sheep red blood cells (SRBC) hemolysis. For the measurement of total immunoglobulin (total lg), the samples were sedimented with a polyethene glycol solution (12.5\%) (Sigma). The total Ig was then determined after calculating protein concentrations before and after sedimentation (Siwicki and Anderson, 2000). 
Protease activity in mucus was measured using the azocasein hydrolysis approach explained by Ross et al. (2000). Mucus alkaline phosphatase (ALP) activity and total protein (TP) level were determined by a commercial kit (Pars Azmun Co., Iran).

\subsection{Statistical analysis}

The data related to the studied indices were analyzed by one-way analysis of variance (ANOVA) using SPSS version 20 software. The significance level of statistical tests was considered less than $5 \%$. Prior to analysis of variance, normality of data distribution and homogeneity of variance of different experimental groups were assessed using Shapiro-Wilk and Levene's tests, respectively. If the results of analysis of variance were significant, Tukey's post hoc test was used to compare the means of different treatments. The mean data were reported as Mean \pm standard error (SE).

\section{Results}

The analysis of the growth and nutritional performance of common carp fed with SEO exposed to different concentrations of pretilachlor herbicide is presented in Table 2.

Table 2

Effect of dietary supplementation with Satureja hortensis and/or exposure to sub-lethal pretilachlor toxicity (1/2 and $1 / 4$ $\left.\mathrm{LC}_{50} ; \mathrm{mg} / \mathrm{l}\right)$ for 21 days on the growth performance and survivability of Cyprinus carpio.

\begin{tabular}{|c|c|c|c|c|c|c|}
\hline Parameters & $\mathrm{T} 1$ & $\mathrm{~T} 2$ & T3 & T4 & T5 & T6 \\
\hline IW (g) & $25.29 \pm 0.53$ & $25.26 \pm 0.29$ & $25.30 \pm 0.41$ & $25.37 \pm 0.26$ & $25.61 \pm 0.41$ & $25.25 \pm 0.31$ \\
\hline FW (g) & $32.86 \pm 1.22^{c}$ & $29.65 \pm 1.30^{\mathrm{ab}}$ & $28.85 \pm 1.48^{a}$ & $34.73 \pm 1.12^{d}$ & $30.72 \pm 1.44^{b}$ & $30.30 \pm 0.92^{\mathrm{ab}}$ \\
\hline WG (g) & $7.57 \pm 0.55^{b}$ & $4.38 \pm 0.03^{a}$ & $3.55 \pm 0.26^{\mathrm{a}}$ & $9.36 \pm 0.39^{b}$ & $5.10 \pm 0.69^{a}$ & $5.04 \pm 0.07^{a}$ \\
\hline WG (\%) & $30.03 \pm 2.70^{b}$ & $17.37 \pm 0.33^{a}$ & $14.06 \pm 1.25^{\mathrm{a}}$ & $36.91 \pm 1.82^{b}$ & $20.03 \pm 3.02^{\mathrm{a}}$ & $19.98 \pm 0.14^{a}$ \\
\hline FCR & $1.77 \pm 0.02^{b c}$ & $1.81 \pm 0.01^{d}$ & $1.82 \pm 0.01^{d}$ & $1.47 \pm 0.02^{\mathrm{a}}$ & $1.68 \pm 0.01^{b}$ & $1.70 \pm 0.01^{b}$ \\
\hline $\operatorname{SGR}\left(\% d^{-1}\right)$ & $0.43 \pm 0.035^{b}$ & $0.26 \pm 0.004^{a}$ & $0.21 \pm 0.018^{a}$ & $0.52 \pm 0.022^{b}$ & $0.30 \pm 0.041^{a}$ & $0.30 \pm 0.002^{a}$ \\
\hline SR (\%) & $93.33 \pm 1.33^{b c}$ & $89.33 \pm 1.33^{b}$ & $82.66 \pm 1.33^{a}$ & $98.66 \pm 1.33^{c}$ & $93.33 \pm 1.33^{b c}$ & $90.66 \pm 1.33^{b}$ \\
\hline \multicolumn{7}{|c|}{$\begin{array}{l}{ }^{*} \text { Mean values with different superscripts }(a, b, c, d) \text { in the same row are significantly different from each other. } \\
\text { Significance level is defined as } p<.05 \text {. }\end{array}$} \\
\hline
\end{tabular}

At the end of the experimental period, the final weight showed a statistically significant difference between the control treatment and the experimental treatments with SEO and pretilachlor herbicide $(P<0.05)$, so that the highest mean weight was obtained in the treatment $\mathrm{T}_{4}(34.73 \pm 1.12 \mathrm{~g})$ and the lowest mean weight was obtained in the treatment $\mathrm{T}_{2}(29.65 \pm$ $1.30 \mathrm{~g})$.

In the present study, the feed conversion ratio (FCR) had a statistically significant difference between control and experimental treatments $(P<0.05)$, so that the lowest and highest values were related to the treatments $T_{4}$ and $T_{3}$, respectively (Table 2 ).

Concerning the daily growth rate, the control treatment was significantly different from other treatments, except the treatment $T_{4}(P<0.05)$, but the other treatments showed no statistically significant difference $(P<0.05)$. 
Table 3 presents the effects of SEO and pretilachlor herbicide on serum biochemical factors separately.

Table 3

Effect of dietary supplementation with Satureja hortensis and/or exposure to sub-lethal Pretilachlor toxicity (1/2 and 1/4 $\left.\mathrm{LC}_{50} ; \mathrm{mg} / \mathrm{l}\right)$ for 21 days on the serum biochemical indices of Cyprinus carpio.

\begin{tabular}{|c|c|c|c|c|c|c|}
\hline Parameters & $\mathrm{T} 1$ & $\mathrm{~T} 2$ & T3 & T4 & T5 & T6 \\
\hline $\begin{array}{l}\text { Total } \\
\text { Protein } \\
\text { (g/dL) }\end{array}$ & $3.19 \pm 0.02^{\mathrm{cd}}$ & $2.85 \pm 0.05^{b}$ & $2.23 \pm 0.06^{a}$ & $3.42 \pm 0.03^{d}$ & $3.10 \pm 0.03^{c}$ & $2.97 \pm 0.06^{b c}$ \\
\hline $\begin{array}{l}\text { Albumin } \\
\text { (g/dL) }\end{array}$ & $2.11 \pm 0.032^{c}$ & $1.89 \pm 0.031^{a b}$ & $1.80 \pm 0.023^{a}$ & $2.13 \pm 0.017^{c}$ & $1.93 \pm 0.027^{b}$ & $1.84 \pm 0.008^{a b}$ \\
\hline $\begin{array}{l}\text { Globulin } \\
\text { (g/dL) }\end{array}$ & $1.08 \pm 0.05^{b c}$ & $0.95 \pm 0.05^{b}$ & $0.43 \pm 0.08^{a}$ & $1.29 \pm 0.05^{c}$ & $0.16 \pm 0.05^{b c}$ & $1.12 \pm 0.06^{b c}$ \\
\hline $\begin{array}{l}\text { Triglyceride } \\
(\mathrm{mg} / \mathrm{dL})\end{array}$ & $125.68 \pm 1.45^{b}$ & $134.05 \pm 1.96^{c}$ & $139.13 \pm 1.40^{c}$ & $112.95 \pm 1.51^{a}$ & $119.74 \pm 1.47^{a b}$ & $123.90 \pm 1.18^{\mathrm{b}}$ \\
\hline $\begin{array}{l}\text { Cholesterol } \\
(\mathrm{mg} / \mathrm{dL})\end{array}$ & $180.90 \pm 2.14^{b}$ & $197.64 \pm 1.79$ de & $204.70 \pm 2.41^{\mathrm{e}}$ & $159.03 \pm 2.95^{a}$ & $184.86 \pm 2.43^{b c}$ & $192.56 \pm 2.46^{\mathrm{cd}}$ \\
\hline $\begin{array}{l}\text { Glucose } \\
\text { (mg/dL) }\end{array}$ & $62.78 \pm 1.36^{b}$ & $70.86 \pm 1.47^{c}$ & $71.47 \pm 1.06^{c}$ & $55.49 \pm 0.91^{a}$ & $64.70 \pm 0.74^{b}$ & $64.93 \pm 1.47^{b}$ \\
\hline $\begin{array}{l}\text { Cortisol } \\
\text { (nmol/L) }\end{array}$ & $83.51 \pm 0.85^{\mathrm{b}}$ & $92.09 \pm 1.27^{d}$ & $99.39 \pm 1.15^{\mathrm{e}}$ & $68.50 \pm 1.36^{a}$ & $85.50 \pm 0.86^{b c}$ & $90.44 \pm 1.09^{\mathrm{cd}}$ \\
\hline LDH (U/L) & $216.84 \pm 2.59 \mathrm{bc}$ & $232.08 \pm 1.87^{\mathrm{cd}}$ & $241.76 \pm 1.77^{d}$ & $196.70 \pm 2.52^{\mathrm{a}}$ & $213.21 \pm 4.58^{b}$ & $215.62 \pm 4.72^{b}$ \\
\hline
\end{tabular}

The total protein content and globulin level were increased with the addition of SEO (treatment $\left.\mathrm{T}_{4}\right)(3.42 \pm 0.03$ ) compared to the control treatment $(3.19 \pm 0.02)$ and showed a statistically significant difference $(P<0.05)$, but the total protein content and globulin level in the treatments $T_{2}$ and $T_{3}$ decreased compared to the control group and had a statistically significant difference with the control group $(P<0.05)$.

The levels of TRIG, CORT, GLU, CHOL and LDH parameters decreased with the addition of SEO (treatment $\mathrm{T}_{4}$ ) compared to the control group and exhibited a statistically significant difference with the control $(P<0.05)$. The CORT had the highest level $(92.09 \pm 1.27)$ in the treatment $T_{3}$ (high concentration of pretilachlor herbicide) and the lowest level (68.50 \pm 1.36) in treatment $T_{4}$. The trend of GLU changes was similar to CORT, the lowest level of which was recorded in the treatment $\mathrm{T}_{4}$ (Table 3).

Table 4 presents the results of liver enzyme assay for the SEO-fed common carp exposed to pretilachlor herbicide. Addition of SEO to common carp diet caused a significant decrease in ALP enzyme compared to the control treatment $(P<0.05)$. The activity level of this enzyme increased in treatments $T_{2}, T_{3}$ and $T_{6}$ and had a significant difference with the control group $(P<0.05)$. Addition of SEO caused a significant decrease in the activity level of AST compared to the control treatment $(P<0.05)$ and the activity level of this enzyme increased in the treatments $T_{2}, T_{3}$ and $T_{6}$ and had a significant difference with the control group $(P<0.05)$. As can be seen in Table 4, the activity level of ALP in the treatment $T_{3}$ had the highest value $(26.14 \pm 0.41)$ and showed a significant difference $(P<0.05)$ with the control treatment, while this parameter had the lowest value in the treatment $\mathrm{T}_{4}(21.44 \pm 0.42)$. 
Table 4

Effect of dietary supplementation with Satureja hortensis and/or exposure to sub-lethal pretilachlor toxicity (1/2 and 1/4 $\mathrm{LC}_{50} ; \mathrm{mg} / \mathrm{l}$ ) for 21 days on Liver enzymes (alanine aminotransferase, aspartate aminotransferase and alkaline phosphatase activities) in the blood plasma of Cyprinus carpio.

\begin{tabular}{|lllllll|}
\hline Parameters & T1 & T2 & T3 & T4 & T5 & T6 \\
\hline ALT $(\mathrm{U} / \mathrm{ml})$ & $16.16 \pm 0.56^{\mathrm{abc}}$ & $18.11 \pm 0.33^{\mathrm{cd}}$ & $19.21 \pm 0.61^{\mathrm{d}}$ & $14.33 \pm 0.30^{\mathrm{a}}$ & $14.70 \pm 0.31^{\mathrm{ab}}$ & $16.60 \pm 0.48^{\mathrm{bc}}$ \\
\hline AST $(\mathrm{U} / \mathrm{ml})$ & $10.38 \pm 0.48^{\mathrm{ab}}$ & $10.86 \pm 0.40^{\mathrm{ab}}$ & $14.89 \pm 0.96^{\mathrm{c}}$ & $08.31 \pm 0.34^{\mathrm{a}}$ & $10.23 \pm 0.35^{\mathrm{ab}}$ & $12.30 \pm 0.52^{\mathrm{bc}}$ \\
\hline ALP $(\mathrm{U} / \mathrm{ml})$ & $23.00 \pm 0.53^{\mathrm{ab}}$ & $24.88 \pm 0.50^{\mathrm{bc}}$ & $26.14 \pm 0.41^{\mathrm{c}}$ & $21.44 \pm 0.42^{\mathrm{a}}$ & $23.61 \pm 0.53^{\mathrm{ab}}$ & $24.63 \pm 0.71^{\mathrm{bc}}$ \\
\hline $\begin{array}{l}\text { *Mean values with different superscripts }(\mathrm{a}, \mathrm{b}, \mathrm{c}, \mathrm{d}) \text { in the same row are significantly different from each other. } \\
\text { Significance level is defined as } \mathrm{p}<.05 .\end{array}$ & & & & \\
\hline
\end{tabular}

According to Table 5, based on the results obtained from serum antioxidant indices, the levels of CAT, SOD and GPX indices increased in the treatment $T_{4}$ and had a statistically significant difference with the control group $(P<0.05)$. However, the MDA content decreased in this treatment and increased in the treatments $T_{2}$ and $T_{3}$.

Table 5

Effect of dietary supplementation with Satureja hortensis and/or exposure to sub-lethal Pretilachlor toxicity (1/2 and 1/4 $\left.\mathrm{LC}_{50} ; \mathrm{mg} / \mathrm{l}\right)$ for 21 days on the serum Antioxidant biomarkers of Cyprinus carpio.

\begin{tabular}{|lllllll|}
\hline Parameters & T1 & T2 & T3 & T4 & T5 & T6 \\
\hline CAT $(\mathrm{U} / \mathrm{ml})$ & $21.17 \pm 0.70^{\mathrm{c}}$ & $16.17 \pm 0.22^{\mathrm{ab}}$ & $17.62 \pm 0.34^{\mathrm{b}}$ & $27.23 \pm 0.52^{\mathrm{d}}$ & $14.82 \pm 0.34^{\mathrm{a}}$ & $15.91 \pm 0.16^{\mathrm{ab}}$ \\
\hline SOD $(\mathrm{U} / \mathrm{ml})$ & $39.35 \pm 0.90^{\mathrm{ab}}$ & $37.30 \pm 0.85^{\mathrm{ab}}$ & $35.65 \pm 0.75^{\mathrm{a}}$ & $41.15 \pm 1.41^{\mathrm{b}}$ & $38.02 \pm 0.6^{\mathrm{ab}}$ & $37.09 \pm 1.54^{\mathrm{ab}}$ \\
\hline MDA $(\mathrm{nmol} / \mathrm{ml})$ & $1.64 \pm 0.11^{\mathrm{b}}$ & $2.15 \pm 0.09^{\mathrm{cd}}$ & $2.27 \pm 0.08^{\mathrm{d}}$ & $1.04 \pm 0.05^{\mathrm{a}}$ & $1.63 \pm 0.03^{\mathrm{b}}$ & $1.85 \pm 0.08^{\mathrm{bc}}$ \\
\hline GPx (U/ml) & $50.09 \pm 0.82^{\mathrm{a}}$ & $48.17 \pm 0.42^{\mathrm{a}}$ & $47.09 \pm 0.91^{\mathrm{a}}$ & $59.85 \pm 1.15^{\mathrm{b}}$ & $50.63 \pm 0.66^{\mathrm{a}}$ & $50.67 \pm 0.85^{\mathrm{a}}$ \\
\hline $\begin{array}{l}\text { *Mean values with different superscripts }(\mathrm{a}, \mathrm{b}, \mathrm{c}, \mathrm{d}) \text { in the same row are significantly different from each other. } \\
\text { Significance level is defined as } \mathrm{p}<.05 .\end{array}$ & & & & \\
\hline *Abbreviations: CAT, catalase; SOD, superoxide dismutase; MDA, malondialdehyde; GPx; glutathione peroxidase
\end{tabular}

As can be seen in Table 6, the serum lysozyme activity did not show a significant difference only in the treatment $T_{5}$ with the control treatment $(P<0.05)$, and its level in the treatments $T_{2}, T_{3}$ and $T_{6}$ decreased compared to the control group and exhibited a significant difference $(P<0.05)$. This was while the treatment $T_{4}$ showed the highest level $(17.70 \pm 0.45)$ of serum lysozyme. 
Table 6

Effect of dietary supplementation with Satureja hortensis and/or exposure to sub-lethal Pretilachlor toxicity (1/2 and $1 / 4$ $\left.\mathrm{LC}_{50} ; \mathrm{mg} / \mathrm{l}\right)$ for 21 days on the Serum Immunological indices (lysozyme activity, alternative complement activity $\left(\mathrm{ACH}_{50}\right)$ and total immunoglobulin) of Cyprinus carpio.

\begin{tabular}{|lllllll|}
\hline Parameters & T1 & T2 & T3 & T4 & T5 & T6 \\
\hline Lysozyme $(\mathrm{U} / \mathrm{ml})$ & $15.66 \pm 0.32^{\mathrm{b}}$ & $12.36 \pm 0.43^{\mathrm{a}}$ & $10.66 \pm 0.34^{\mathrm{a}}$ & $17.70 \pm 0.45^{\mathrm{c}}$ & $15.03 \pm 0.40^{\mathrm{b}}$ & $12.03 \pm 0.17^{\mathrm{a}}$ \\
\hline $\mathrm{ACH}_{50}(\mathrm{U} / \mathrm{ml})$ & $45.30 \pm 1.88^{\mathrm{ab}}$ & $43.40 \pm 2.67^{\mathrm{ab}}$ & $36.77 \pm 1.91^{\mathrm{a}}$ & $54.14 \pm 2.98^{\mathrm{b}}$ & $47.50 \pm 2.85^{\mathrm{b}}$ & $40.96 \pm 1.75^{\mathrm{a}}$ \\
\hline Total lg $(\mathrm{mg} / \mathrm{ml})$ & $20.52 \pm 0.84^{\mathrm{b}}$ & $15.13 \pm 0.80^{\mathrm{a}}$ & $17.65 \pm 0.98^{\mathrm{ab}}$ & $26.62 \pm 0.84^{\mathrm{c}}$ & $18.40 \pm 0.86^{\mathrm{ab}}$ & $20.43 \pm 0.73^{\mathrm{b}}$ \\
\hline $\begin{array}{l}\text { *Mean values with different superscripts }(\mathrm{a}, \mathrm{b}, \mathrm{c}) \text { in the same row are significantly different from each other. } \\
\text { Significance level is defined as } \mathrm{p}<.05 .\end{array}$ & & & & \\
\hline
\end{tabular}

The highest level of serum complement $\left(\mathrm{ACH}_{50}\right)$ showed that its level increased in the treatments $\mathrm{T}_{4}$ and $\mathrm{T}_{5}$ compared to the control, which had the highest mean in the treatment $\mathrm{T}_{4}(54.14 \pm 2.9)$ (Table 6). As can be seen in Table 6, the $\mathrm{ACH}_{50}$ activity was the highest in the treatment $\mathrm{T}_{4}(36.84 \pm 1.13)$ and displayed a significant difference with the control treatment $(33.05 \pm 0.86)(P<0.05)$.

Tables 6 and Fig. 1 present the effect of SEO and pretilachlor herbicide on indicators related to immune serum and mucosal immune system. The results showed the highest mucosal lysozyme activity in the treatment $\mathrm{T}_{4}(29.32 \pm 0.64)$, which was significantly different from other treatments and the control group $(27.07 \pm 0.60)(P<0.05)$. The treatments $T_{2}$ and $T_{3}$, which received the low and high concentrations of pretilachlor herbicide, respectively, showed a decrease in lysozyme level, which was significantly different from the control group $(P<0.05)$.

The highest level of mucosal immunoglobulin was obtained in the treatment $T_{4}(11.22 \pm 0.53 \mathrm{mg} / \mathrm{L})$, which showed a significant difference with the control group.

The protease level increased in the treatment $\mathrm{T}_{4}(20.30 \pm 0.84)$ compared to the control treatment $(19.15 \pm 0.84)$ and displayed a statistically significant difference $(P<0.05)$ but its level decreased in the other treatments compared to the control.

\section{Discussion}

Special attention has recently been paid to the use of immunostimulants as dietary supplements capable of improving nonspecific defense and developing resistance to pathogens and toxins during the onset of multiple stresses during the breeding season (Antache et al. 2014; Jahanjoo et al. 2018; Yousefi et al. 2020; Farag et al. 2021; Ghafarifarsani et al. 2021c; Owolabi and Abdulkareem 2021; Ghafarifarsani et al. 2022; Raissy et al. 2022). Due to the medicinal importance and many benefits of summer savory, the aim of this study was to investigate the protective effect of essential oil of this plant (SEO) on various parameters of common carp exposed to pretilachlor herbicide as an important species in aquaculture. Since measuring the trend of changes in biochemical factors, antioxidant enzymes and immunological factors of serum and mucus can be considered as a suitable tool for predicting and determining the health of a living organism, these factors can also be used to determine the drug safety (Subramanian et al. 2007; Mauri et al. 2011; Harikrishnan et al. 2011; Yonar and Sakin 2011; Hedayati et al. 2019; Bisht et al. 2020; Vali et al. 2020; Farag et al. 2021). Considering the effect of SEO on various parameters of common carp, it can be said that the use of the essential oil of this plant is unimpeded to improve the health and growth and strengthen the immune system of fish. According to the results, the highest survival rate, final weight, daily growth rate and specific growth rate were observed in the SEO- 
containing treatments. Accordingly, all growth parameters were reduced in the treatments $T_{2}$ and $T_{3}$, which contained low and high concentrations of pretilachlor herbicide, compared to the control group. However, the growth parameters showed better conditions in the treatments $T_{5}$ and $T_{6}$, which were co-administered with toxin and SEO, than the treatments $T_{2}$ and $T_{3}$. This was while the best growth performance conditions were recorded in the treatment $T_{4}$ (recipient of 1\%SEO), so the impact of SEO on growth parameters is clearly shown. Mohamadi Saei et al. (2016) investigated the effects of diet containing different levels of Myrtus communis and Satureja khuzestanica extracts on growth, survival and nutritional indices of rainbow trout. They reported that the highest feed conversion ratio was observed in fish fed diets containing M. communis and S. khuzestanica extracts, which is similar to the results of the present study. Studies have shown that the immunostimulants or antioxidant compounds can improve animal growth by eliminating inflammatory markers and restoring the integrity of the gastrointestinal wall (Niewold 2014; Celi et al. 2019). Yousefi et al. (2021b) investigated the effect of different levels of Origanum majorana extract (from Lamiaceae family) on growth, hematological, immunological and biochemical parameters of common carp (Cyprinus carpio), and observed that there are significant effects of marjoram extract on fish growth performance. Numerous studies have also shown that the Labiatae family (which includes several plants such as Thymus vulgaris and Origanum vulgare) are plants known for their growth-promoting, antioxidant and immunostimulatory properties in fish (Zheng et al. 2009; Diler et al. 2017; Zargar et al. 2019; Abdel-Latif et al. 2020).

In the present study, the use of SEO reduced the level of TRIG and CHOL in the common carp compared to the control group and showed a significant difference between them. In fact, the extracts of some plants increase the excretion of $\mathrm{CHOL}$ and decrease the synthesis of cellular $\mathrm{CHOL}$ by increasing the level of Cholesterol 7a-hydroxylase activity in liver cells, resulting in a decrease in the levels of CHOL and TRIG in the blood (Asgary et al. 2000). Measuring blood GLU levels is a common factor in assessing stress levels in fish that are affected by environmental stresses, nutritional status, and manipulation (Prasad and Charles 2010). The present study showed that the SEO-containing treatments reduced the GLU levels in fish fed with this essential oil. At the end of the experimental period, the total protein content of SEO-treated fish increased significantly compared to the control group. The results of the present study on common carp showed that the use of SEO-containing diets led to an increase in the total protein content of fish serum. Elevated serum albumin and globulin levels are known to boost immunity in fish. In the present study, the serum globulin and albumin levels in the SEO-containing treatments increased compared to the control. Asadi et al. (2012) investigated the effect of Nasturtium nasturtium extract on rainbow trout and found that the extract of this plant increased fish blood globulin.

The AST, ALT, and ALP are important enzymes for exploring tissue and muscle damage, especially liver tissue, which are secreted into the circulation following liver tissue damage, and an increase in their serum levels indicates liver damage (Paris-Palacios et al. 2000; Orisakwe et al. 2003). Therefore, liver enzymes as stress indicators can be major players in monitoring toxicological changes in the environment (Brusle and Anadon 2017; Abdel-Latif et al. 2020). In the present study, the pretilachlor herbicide increased all three enzymes compared to the control group, but the addition of SEO to the treatments decreased the levels of these "enzymes" in the blood. This suggests that the SEO improves liver tissue damage caused by pretilachlor herbicide and reduces liver enzymes in the blood. A similar result was observed in the study of feeding rainbow trout (Hoseini and Yousefi 2019) and common carp (Ghafarifarsani et al. 2021a) with thyme extract. In general, the addition of pretilachlor herbicide to experimental treatments caused damage to liver tissue; as a result, the activity of these enzymes increased at the serum level, and the positive effect of plant extracts on the liver enzymes of fish exposed to toxins has been reported. The hepatoprotective effects of plants can be attributed to their antioxidant activity, which is mainly due to their ability to eliminate free radicals or inhibit lipid peroxidation (Farag et al. 1989).

Proper functioning of the antioxidant system is an important and vital factor in the health of fish and plant materials are useful and beneficial additives due to the presence of natural antioxidants (Yousefi et al. 2021a,b). Numerous studies have shown that the chemical composition of summer savory contains high amounts of carvacrol along with other

Page $11 / 19$ 
phenolic compounds, flavonoids, triterpenoids, steroids and tannins (Farsam et al. 2004). Therefore, it has been stated that savory has effective antioxidant properties. The MDA content is evaluated as an indicator of lipid peroxidation in fish blood plasma (Yousefi et al. 2021b), which increased in pretilachlor herbicide treatments in the present study and decreased with the addition of SEO to the treatments. In line with the decrease in MDA content, the activity of SOD and GPX antioxidant enzymes in SEO-containing treatments increased compared to the control group and treatments containing pretilachlor herbicide. In fact, the phenolic compounds of savory due to its benzene ring and electron resonance can trap free radicals and prevent the continuation of chain reactions and the production of other free radicals (Farahi et al. 2012; Roby et al. 2013). Similarly, such results were reported for MDA and other antioxidant enzymes in the study of the effect of marjoram (from the Labiatae family) on common carp (Yousefi et al. 2021b), the effect of Shirazi thyme (Zataria multiflora) on rainbow trout (Mirghaed et al. 2020), as well as the effect of oregano (Origanum vulgare) on common carp (Abdel-Latif et al. 2020). The lysozyme is one of the most important non-specific immune components of fish, which destroys the bacterial wall, activates complement and increases phagocytic activity (Sakai 1999; Saurabh and Sahoo 2008). Increased serum lysozyme activity indicates an improvement in the immune status of fish and its increase helps to better control the immune system of fish against infectious and pathogenic agents (Ring $\varnothing$ et al. 2012; Li et al. 2018). The present study, the lysozyme levels decreased in treatments containing pretilachlor herbicide and showed a statistically significant difference compared to the control group, but lysozyme levels increased with the addition of SEO which seems to be due to the stimulatory ability of active ingredients of SEO (gamma-Terpinene and carvacrol). Therefore, this practice shows that SEO increases the level of immunity and resistance of common carp exposed to pretilachlor herbicide. These results were consistent with the study of Khansari et al. (2013) who evaluated the effect of Khuzestani savory on the parameters of immunity and hematology in the common carp (Cyprinus carpio). The complement system is a collection of more than 35 types of serum proteins that are very closely related and controlled to each other and other molecules of the immune system (Sunyer et al. 1997). The most important task of this system is to kill microorganisms through phagocytic processes, inflammatory reactions, clearance of immune complexes, induction and improvement of antibody responses (Mauri et al. 2011). In the present study, the highest values of complement system factors were observed in the treatment containing SEO and showed a significant difference with the control group. Changes in serum complement are very important in protecting the nonspecific immune system of fish, and high levels of complement indicate the health of the fish (Yano 1992). Other studies have shown that consumption of peppermint stimulated the activity of complement system components in rainbow trout (Adel et al. 2015). The ACH 50 activity and total Ig level as indicators of immune status may be suppressed in fish exposed to toxins (Wang et al. 2014; Sharifian et al. 2015). The total Ig level decreased in fish exposed to pretilachlor herbicide compared to the control group, but increased in the SEO-containing group. Hoseini and Yousefi (2019) investigated the effect of thyme (Thymus vulgaris) extract on rainbow trout and reported a significant increase in the lysozyme, $\mathrm{ACH}_{50}$ and total lg levels.

\section{Conclusions}

To conclude, the results of this study demonstrated that the addition of summer savory (Satureja hortensis) essential oil to the diets of fish in exposure to stressful conditions and toxin-induced contamination improved digestion and absorption of nutrients, promoted better growth, increased antioxidant capacity and boosted the immune system of fish, and thus exerted a protective effect for the common carp species.

\section{Declarations}

\section{Funding}

This research did not receive any specific grant from funding agencies in the public, commercial, or not-for-profit sectors.

\section{Conflicts of interest/Competing interests}

Page $12 / 19$ 
There is no conflict of interest to declare.

\section{Ethics approval}

All applicable international, national, and/or institutional guidelines for the care and use of animals were followed. All experiments were performed following the protocol approved by the committee of ethics of the faculty of sciences of the University of Tehran (357; 8 November 2000).

\section{Consent to participate}

Not applicable

\section{Consent for publication}

All authors give consent for publication.

\section{Availability of data and material}

The datasets generated during and/or analysed during the current study are available from the corresponding author on reasonable request.

\section{Code availability}

Not applicable

\section{Authors' contributions}

Conceptualization, Turki Jalil; methodology, Shahbazi Naserabad., Abdelbasset and Turki Jalil; software, Widjaja and Altimari; validation, Turki Jalil, Widjaja; data curation, Aravindhan, Attia Thijail; writing original draft preparation, Shahbazi Naserabad, Abdelbasset; writing-review and editing, Turki Jalil, Fakri Mustafa, Widjaja; supervision, Turki Jalil and Widjaja; project administration, Turki Jalil. All authors have read and agreed to the published version of the manuscript.

\section{References}

1. Abdel-Latif HM, Abdel-Tawwab M, Khafaga AF, Dawood MA (2020) Dietary oregano essential oil improved the growth performance via enhancing the intestinal morphometry and hepato-renal functions of common carp (Cyprinus carpio L.) fingerlings. Aquaculture, 526:735432.

2. Abdel-Latif HM, Abdel-Tawwab M, Khafaga AF, Dawood MA (2020) Dietary origanum essential oil improved antioxidative status, immune-related genes, and resistance of common carp (Cyprinus carpio L.) to Aeromonas hydrophila infection. Fish Shellfish Immunol 104:1-7.

3. Abdel-Tawwab M, El-Araby DA (2021) Immune and antioxidative effects of dietary licorice (Glycyrrhiza glabra L.) on performance of Nile tilapia, Oreochromis niloticus (L.) and its susceptibility to Aeromonas hydrophila infection. Aquaculture 530:735828.

4. Abdel-Tawwab M, Ahmad MH, Seden ME, Sakr SF (2010) Use of green tea, Camellia sinensis L., in practical diet for growth and protection of Nile tilapia, Oreochromis niloticus (L.), against Aeromonas hydrophila infection. J World Aquac Soc 41:203-213.

5. Adel M, Pourgholam R, Zorriehzahra SJ, Ghiasi M (2015) The effect of different level of Mentha piperita on some of the hematological, biochemical and immune parameters of Oncorhynchus mykiss. Iran Fish Sci J 24(1):37-46. 
6. Agrahari S, Pandey KC, Gopal K (2007) Biochemical alteration induced by monocrotophos in the blood plasma of fish, Channa punctatus (Bloch). Pestic Biochem Physiol 88(3):268-272.

7. Akbarzadeh M (2003) Medicinal Plants of Labiatae Family in the summer rangelands of Vaz region in Mazandaran Province. Iran J Med Arom Plants Res 19(1):37-46.

8. Alagawany M, Farag MR, Abdelnour SA, Elnesr SS (2021) A review on the beneficial effect of thymol on health and production of fish. Rev Aquac 13(1):632-641.

9. Alishahi M, Soltani M, Mesbah M, Rad AE 2011. Effects of dietary Silybum marianum extract on immune parameters of the common carp (Cyprinus carpio). J Vet Res 66(3):255-286.

10. Antache A, Cristea V, Grecu I, Dediu L, Cretu M, Bocioc E, Petrea SM (2014) Effects of Dietary Supplementation at Nile tilapia with Thymus vulgaris, Trigonela foenum graecum and Azadirachta indica on Welfare Status Bull Univ Agric Sci Vet Med Cluj-Napoca Anim Sci Biotechnol 71(2):115-122.

11. Asadi MS, Mirvaghefei AR, Nematollahi MA, Banaee M, Ahmadi K (2012) Effects of Watercress (Nasturtium nasturtium) extract on selected immunological parameters of rainbow trout (Oncorhynchus mykiss). Open Vet $\mathrm{J}$ 2(1):32-39.

12. Asgary S, Naderi GH, Sarrafzadegan N, Mohammadifard N, Mostafavi S, Vakili R (2000) Antihypertensive and antihyperlipidemic effects of Achillea wilhelmsii. Drugs Exp Clin Res 26(3):89-94.

13. Awad E, Awaad A (2017) Role of medicinal plants on growth performance and immune status in fish. Fish Shellfish Immunol 67:40-54.

14. Bagenal T (1978) Methods for assessment of fish production in fresh waters (No. 597.052632 M4 1978). Oxford. London 365p.

15. Betoulle S, Duchiron C, Deschaux P (2000) Lindane differently modulates intracellular calcium levels in two populations of rainbow trout (Oncorhynchus mykiss) immune cells: head kidney phagocytes and peripheral blood leucocytes. Toxicology 145(2-3):203-215.

16. Bisht M, Kumar A, Shah TK (2020) Effect of Moringa oleifera leaf powder on skin mucosal immune responses and growth performance of guppy, Poecilia reticulata (Peter, 1860). Aquacult Res 51(12): 4984-4990.

17. Blahová, J et al (2013) Oxidative stress responses in zebrafish Danio rerio after subchronic exposure to atrazine. Food Chem Toxicol 61:82-85.

18. Brusle J, Anadon GG 2017. The structure and function of fish liver. In Fish morphology (pp. 77-93). Routledge.

19. Celi P, Verlhac V, Calvo EP, Schmeisser J, Kluenter AM (2019) Biomarkers of gastrointestinal functionality in animal nutrition and health. Anim Feed Sci Technol 250:9-31.

20. Choudhury PP, Barman KK. Varshney JG, (2009) Photolysis of pretilachlor on soil surface. Indian J Weed Sci 41(12):87-89.

21. Diler O, Gormez O, Diler I, Metin SEÇiL (2017) Effect of oregano (Origanum onites L.) essential oil on growth, lysozyme and antioxidant activity and resistance against Lactococcus garvieae in rainbow trout, Oncorhynchus mykiss (Walbaum). Aquac Nutr 23(4): 844-851.

22. Dügenci SK, Arda N, Candan A (2003) Some medicinal plants as immunostimulant for fish. J Ethnopharmacol 88(1):99-106.

23. Farag MR, Alagawany M, Khalil SR, Moustafa, AA, Mahmoud HK, Abdel-Latif HM (2021) Astragalus membranaceus polysaccharides modulate growth, hemato-biochemical indices, hepatic antioxidants, and expression of HSP70 and apoptosis-related genes in Oreochromis niloticus exposed to sub-lethal thallium toxicity. Fish Shellfish Immunol 118:251-260.

24. Farag RS, Badei AZMA, Hewedi FM, El-Baroty GSA (1989) Antioxidant activity of some spice essential oils on linoleic acid oxidation in aqueous media. J Am Oil Chem Soc 66(6):792-799.

Page 14/19 
25. Farahi A, Kasiri M, Sudagar M, Soleimani Iraei M, Zorriehzahra SMJ (2012) Effect of dietary supplementation of Melissa officinalis and Aloe vera on hematological traits, lipid oxidation of carcass and performance in rainbow trout (Oncorhynchus mykiss). Online J Anim Feed Res 1:1-5.

26. Farsam H, Amanlou M, Radpour MR, Salehinia AN, Shafiee A (2004) Composition of the essential oils of wild and cultivated Satureja khuzistanica Jamzad from Iran. Flavour Fragr J 19(4):308-310.

27. FrAnKIČ T, Voljč M, Salobir J, Rezar V (2009) Use of herbs and spices and their extracts in animal nutrition. Acta Agric Slov 94(2):95-102.

28. Galina J, Yin G, Ardo L, Jeney Z (2009) The use of immunostimulating herbs in fish. An overview of research. Fish Physiol Biochem 35(4):669-676.

29. Ghafarifarsan H, Hoseinifar SH, Adorian TJ, Ferrigolo FRG, Raissy M, Van Doan H (2021a) The effects of combined inclusion of Malvae sylvestris, Origanum vulgare, and Allium hirtifolium boiss for common carp (Cyprinus carpio) diet: Growth performance, antioxidant defense, and immunological parameters. Fish Shellfish Immunol 119:670677.

30. Ghafarifarsani H., Hoseinifar SH, Aftabgard M, Van Doan H (2022) The improving role of savory (Satureja hortensis) essential oil for Caspian Roach (Rutilus caspicus) fry: Growth, haematological, immunological, and antioxidant parameters and resistance to salinity stress. Aquaculture.

31. Ghafarifarsani H, Kachuei R, Imani A (2021b). Dietary supplementation of garden thyme essential oil ameliorated the deteriorative effects of aflatoxin B1 on growth performance and intestinal inflammatory status of rainbow trout (Oncorhynchus mykiss). Aquaculture 531:735928.

32. Ghafarifarsani H, Rashidian G, Bagheri T, Hoseinifar SH, Van Doan H (2021c). Study on growth enhancement and the protective effects of dietary prebiotic inulin on immunity responses of rainbow trout (Oncorhynchus mykiss) fry infected with Aeromonas hydrophila. Ann Anim Sci 21(2):543-559.

33. Gilliom RJ (2007) Pesticides in US streams and groundwater. Environ Sci Technol 41:3408-3484.

34. Greathead H (2003) Plants and plant extracts for improving animal productivity. Proc Nutr Soc 62(2):279-290.

35. Hajirezaee S, Mohammadi G, Naserabad SS (2020) The protective effects of vitamin C on common carp (Cyprinus carpio) exposed to titanium oxide nanoparticles (TiO2-NPs). Aquaculture 518:734734.

36. Harikrishnan R, Balasundaram C, Heo MS (2011) Impact of plant products on innate and adaptive immune system of cultured finfish and shellfish. Aquaculture 317(1-4):1-15.

37. Hedayati SA, Farsani HG, Naserabad SS, Hoseinifar SH, Van Doan H (2019) Protective effect of dietary vitamin E on immunological and biochemical induction through silver nanoparticles (AgNPs) inclusion in diet and silver salt (AgNO3) exposure on Zebrafish (Danio rerio). Comp Biochem Physiol C Toxicol Pharmacol 222:100-107.

38. Hedayati SAA, Ghafari Farsani H, Shahbazi Naserabad S, Gerami MH (2015) Acute toxicity and behavioral changes associated with diazinon in Rutilus rutilus caspicus and Hypophthalmicthys molitrix. Iran J Toxicol 9(30):1354-1359.

39. Hernández-Contreras Á, Hernández MD (2020) Application of aromatic plants and their extracts in aquaculture. In Feed Additives. Academic Press.

40. Hladik ML, Bouwer EJ, Roberts AL (2008) Neutral chloroacetamide herbicide degradates and related compounds in Midwestern United States drinking water sources. Sci Total Environ 390(1): pp.155-165.

41. Hoseini SM, Yousefi M (2019) Beneficial effects of thyme (Thymus vulgaris) extract on oxytetracycline-induced stress response, immunosuppression, oxidative stress and enzymatic changes in rainbow trout (Oncorhynchus mykiss). Aquac Nutr 25(2):298-309.

42. Hoseini SM, Hosseini SA, Soudagar M (2012) Dietary tryptophan changes serum stress markers, enzyme activity, and ions concentration of wild common carp Cyprinus carpio exposed to ambient copper. Fish Physiol Biochem 38(5):1419-1426.

Page 15/19 
43. Hoseinifar SH et al (2020) Dietary supplementation of lemon verbena (Aloysia citrodora) improved immunity, immune-related genes expression and antioxidant enzymes in rainbow trout (Oncorrhyncus mykiss). Fish Shellfish Immunol 99:379-385.

44. Hoseinifar SH, Zou HK, Van Doan H, Kolangi Miandare H, Hoseini SM (2018) Evaluation of some intestinal cytokines genes expression and serum innate immune parameters in common carp (Cyprinus carpio) fed dietary loquat (Eriobotrya japonica) leaf extract. Aquacult Res 49(1): 120-127.

45. Jahanjoo V, Yahyavi M, Akrami R, Bahri AH (2018) Influence of Adding Garlic (Allium sativum), Ginger (Zingiber officinale), Thyme (Thymus vulgaris) and Their Combination on the Growth Performance, Haematolmmunological Parameters and Disease Resistance to Photobacterium damselae in Sobaity Sea Bream (Sparidentex hasta) Fry. Turk J Fish Aquat Sci 18(4):633-645.

46. Jiang J, Chen Y, Yu R, Zhao, X, Wang Q, Cai L (2016) Pretilachlor has the potential to induce endocrine disruption, oxidative stress, apoptosis and immunotoxicity during zebrafish embryo development. Environ Toxicol Pharmacol 42:125-134.

47. Kapoorchali MF, Fatemi SR, Vosoghy G, Matinfar M, Sharifian M (2009) Increasing in growth of Rutilus frisii kutum larvae with using slurry (fermented organic manure) in Yosefpoor propagation and rearing center (Iran). J Fish Aquat Sci 4(1):22-31.

48. Khansari A, Yavari V, Alishahi M, Mousavi SM, Ghorbanpoor M, Bastami KD, Azizi S (2013) Effects of Oliviera decumbens and Satureja khuzestanica extract on some immunological and haematological parameters of Cyprinus carpio. Comp Clin Pathol 22(3):339-342.

49. Kumari K (2020) Pesticides toxicity in fishes: A review. J Entomol Zool Stud 8(5), pp.1640-1642.

50. Magnadottir B (2006) Innate immunity of fish (overview). Fish Shellfish Immunol 20, pp.137-151.

51. Mahdavi S, Yeganeh S, Firouzbakhsh F, Janikhalili KH (2014) Effects of supplementary fennel (Foeniculum vulgare) essential oil of diet on growth, survival, body composition and hematological parameters of Rutilus frisii kutum fry. J Fish Sci Technol 3(3):75-87.

52. Mauri l et al (2011) Changes in complement responses in Gilthead seabream (Sparus aurata) and European seabass (Dicentrarchus labrax) under crowding stress, plus viral and bacterial challenges. Fish Shellfish Immunol 30(1):182188.

53. Mirghaed AT, Hoseini SM, Hoseinifar SH, Van Doan H (2020) Effects of dietary thyme (Zataria multiflora) extract on antioxidant and immunological responses and immune-related gene expression of rainbow trout (Oncorhynchus mykiss) juveniles. Fish Shellfish Immunol 106:502-509.

54. Mohamadi Saei M, Beiranvand K, Khalesi MK, Mehrabi F (2016) Effects of dietary savory and myrtle essential oils on growth, survival, nutritional indices, serum biochemistry, and Hematology of farmed rainbow trout, Oncorhynchus mykiss, fry. J World Aquac Soc 47(6):779-785.

55. Mohammadi G, Rashidian G, Hoseinifar SH, Naserabad SS, Van Doan H (2020) Ginger (Zingiber officinale) extract affects growth performance, body composition, haematology, serum and mucosal immune parameters in common carp (Cyprinus carpio). Fish Shellfish Immunol 99:267-273.

56. Myszka K, Olejnik A, Majcher M, Sobieszczańska N, Grygier A, Powierska-Czarny J, Rudzińska M (2019) Green pepper essential oil as a biopreservative agent for fish-based products: Antimicrobial and antivirulence activities against Pseudomonas aeruginosa KM01. LWT 108:6-13.

57. Naiel MA, Negm SS, Abd El-hameed SA, Abdel-Latif HM (2021) Dietary organic selenium improves growth, serum biochemical indices, immune responses, antioxidative capacity, and modulates transcription of stress-related genes in Nile tilapia reared under sub-optimal temperature. J Therm Biol 99:102999. 
58. Niewold TA (2014) Gut health, intestinal immunity and performance. In: Australian Poultry Science Symposium 7277.

59. OECD (1994) OECD Guidelines for the Testing of Chemicals: Organization for Economic.

60. Orisakwe OE, Afonne OJ, Chude, MA, Obi E, Dioka CE (2003) Sub-chronic toxicity studies of the aqueous extract of Boerhavia diffusa leaves. J. Health Sci 49(6):444-447.

61. Owolabi OD, Abdulkareem SI (2021) Carica papaya and Mangifera indica modulate haematological, biochemical and histological alterations in atrazine-intoxicated fish, Clarias gariepinus (Burchell 1822). J Basic Appl Zool 82(1):118.

62. Pandey G, Madhuri S, Mandloi AK (2012) Medicinal plants useful in fish diseases. Plant Arch 12(1):1-4.

63. Paris-Palacios S, Biagianti-Risbourg S, Vernet G (2000) Biochemical and (ultra) structural hepatic perturbations of Brachydanio rerio (Teleostei, Cyprinidae) exposed to two sublethal concentrations of copper sulfate. Aquat Toxicol 50(1-2):109-124.

64. Prasad G, Charles S (2010) Haematology and leucocyte enzyme cytochemistry of a threatened yellow catfish Horabagrus brachysoma (Gunther 1864). Fish Physiol Biochem 36(3):435-443.

65. Puangkaew J, Kiron V, Satoh S, Watanabe T (2005) Antioxidant defense of rainbow trout (Oncorhynchus mykiss) in relation to dietary n-3 highly unsaturated fatty acids and vitamin E contents. Comp Biochem Physiol C Toxicol Pharmacol 140(2):187-196.

66. Raissy M, Ghafarifarsani H, Hoseinifar SH, El-Haroun ER, Naserabad SS, Van Doan H (2022) The effect of dietary combined herbs extracts (oak acorn, coriander, and common mallow) on growth, digestive enzymes, antioxidant and immune response, and resistance against Aeromonas hydrophila infection in common carp, Cyprinus carpio. Aquaculture 546:737287.

67. Reverter M, Bontemps N, Lecchini D, Banaigs B, Sasal P (2014) Use of plant extracts in fish aquaculture as an alternative to chemotherapy: current status and future perspectives. Aquaculture 433:50-61.

68. Ring $\varnothing$ E, Olsen RE, Vecino JG, Wadsworth S, Song SK (2012) Use of immunostimulants and nucleotides in aquaculture: a review. J Mar Sci Res Dev 2(1):104.

69. Roby MHH, Sarhan MA, Selim KAH, Khalel KI (2013) Evaluation of antioxidant activity, total phenols and phenolic compounds in thyme (Thymus vulgaris L.), sage (Salvia officinalis L.), and marjoram (Origanum majorana L.) extracts. Ind Crops Prod 43:827-831.

70. Ross NW, Firth KJ, Wang A, Burka JF, Johnson SC (2000) Changes in hydrolytic enzyme activities of naive Atlantic salmon Salmo salar skin mucus due to infection with the salmon louse Lepeophtheirus salmonis and cortisol implantation. Dis Aquat Org 41(1):43-51.

71. Sakai M (1999) Current research status of fish immunostimulants. Aquaculture 172(1-2):63-92.

72. Sánchez-Fortún S, Barahona MV (2005) Comparative study on the environmental risk induced by several pyrethroids in estuarine and freshwater invertebrate organisms. Chemosphere 59(4):553-559.

73. Saurabh S, Sahoo PK (2008) Lysozyme: an important defence molecule of fish innate immune system. Aquacult Res 39(3):223-239.

74. Shahbazi Naserabad S, Mirvaghefi A, Rashidiyan G, Rostamian N, Ghafari Farsani H (2017) Investigating the Agent of Temperature into Acute Toxicity (LC 50 96h) of Edifenphos in Rutilus Frisii Kutum (Kamensky, 1901). Iran J Toxicol 11(2):39-44.

75. Sharifian I, Rastiannasab A, Gandomkar H (2015) Effects of diazinon on some immunological components of common carp, Cyprinus carpio juveniles. Comp Clin Pathol 24(6):1339-1341.

76. Silambarasan N, Hemalatha S (2015) Protective Role of Vitamin-C Against Malathion Toxicity On Certain Biochemical Parameters In Liver Of Fresh Water Fish. Int J Modn Res Revs 3(11):1058-1061. 
77. Solomon KR, Carr JA, Du Preez LH, Giesy, JP, Kendall RJ, Smith EE, Van Der Kraak GJ (2008) Effects of atrazine on fish, amphibians, and aquatic reptiles: a critical review. Crit Rev Toxicol 38(9):721-772.

78. Soni R, Verma SK (2018) Acute toxicity and behavioural responses in Clarias batrachus (Linnaeus) exposed to herbicide pretilachlor. Heliyon, 4(12):e01090.

79. Srivastava P, Singh A, Pandey AK (2016) Pesticides toxicity in fishes: biochemical, physiological and genotoxic aspects. Biochem Cell Arch 16(2):199-218.

80. Subramanian S, MacKinnon SL, Ross NW (2007) A comparative study on innate immune parameters in the epidermal mucus of various fish species. Comp Biochem Physiol Biochem Mol Biol 148(3):256-263.

81. Suchiang P (2021) A Review on Toxicity of Pesticides in Catfishes: Reproductive, Haematological and Biochemical Aspects. Annu Rev Res Biol 47-59.

82. Sunyer JO, Tort L, Lambris JD (1997) Diversity of the third form of complement, C3, in fish: functional characterization of five forms of C3 in the diploid fish Sparus aurata. Biochem J 326(3):877-881.

83. Taherian SMR, Hosseini SA, Jafari A, Etminan A, Birjandi M (2019) Acute toxicity of Zinc Oxide nanoparticles from Satureja hortensis on Rainbow Trout (Oncorhynchus mykiss). Turk J Fish Aquat Sci 20(6):481-489.

84. Valavanidis A, Vlahogianni T, Dassenakis M, Scoullos M (2006) Molecular biomarkers of oxidative stress in aquatic organisms in relation to toxic environmental pollutants. Ecotoxicol Environ Saf 64(2):178-189.

85. Vali S, Mohammadi G, Tavabe KR, Moghadas F, Naserabad S.S (2020) The effects of silver nanoparticles (Ag-NPs) sublethal concentrations on common carp (Cyprinus carpio): Bioaccumulation, hematology, serum biochemistry and immunology, antioxidant enzymes, and skin mucosal responses. Ecotoxicol Environ Saf 194:110353.

86. Wang T, Long X, Cheng Y, Liu Z, Yan S (2014) The potential toxicity of copper nanoparticles and copper sulphate on juvenile Epinephelus coioides. Aquat Toxicol 152:96-104.

87. Windisch W, Schedle K, Plitzner C, Kroismayr A (2008) Use of phytogenic products as feed additives for swine and poultry. Anim Sci J 86(suppl_14):140-148.

88. Wu G et al (2007) Immunological and biochemical parameters in carp (Cyprinus carpio) after Qompsell feed ingredients for long-term administration. Aquacult Res 38(3):246-255.

89. Xu WANG, Jilong LI, Houjuan XING, Shiwen XU (2011) Review of toxicology of atrazine and chlorpyrifos on fish. J Northeast Agric Univ (Engl Ed) 18(4):88-92.

90. Yano T (1992) Assays of hemolytic complement activity. Techniques in fish immunology 131-141.

91. Yogesh HW, Yashshri AG, Prakash PA (2009) Sublethal and chronic effect of carbaryl and malathion on Clarius batrachus (Linn.). J Appl Sci Environ Manage 13(2):23-26.

92. Yonar ME, Sakin F (2011) Ameliorative effect of lycopene on antioxidant status in Cyprinus carpio during pyrethroid deltamethrin exposure. Pestic Biochem Physiol 99(3);226-231.

93. Yousefi M, Farsani MN, Ghafarifarsani H, Hoseinifar SH, Van Doan H (2021a) The effects of dietary supplementation of mistletoe (Viscum album) extract on the growth performance, antioxidant, and innate, immune responses of rainbow trout (Oncorhynchus mykiss). Aquaculture 536:736385.

94. Yousefi M, Ghafarifarsani H, Hoseinifar SH, Rashidian G, Van Doan H (2021b) Effects of dietary marjoram, Origanum majorana extract on growth performance, hematological, antioxidant, humoral and mucosal immune responses, and resistance of common carp, Cyprinus carpio against Aeromonas hydrophila. Fish Shellfish Immunol 108:127-133.

95. Yousefi M, Vatnikov YA, Kulikov EV, Plushikov VG, Drukovsky SG, Hoseinifar SH, Van Doan H (2020) The protective effects of dietary garlic on common carp (Cyprinus carpio) exposed to ambient ammonia toxicity. Aquaculture 526:735400.

96. Zargar A, Rahimi-Afzal Z, Soltani E, Taheri Mirghaed A, Ebrahimzadeh-Mousavi HA, Soltani M, Yuosefi P (2019) Growth performance, immune response and disease resistance of rainbow trout (Oncorhynchus mykiss) fed Thymus 
vulgaris essential oils. Aquacult Res 50(11):3097-3106.

97. Zheng ZL, Tan JY, Liu HY, Zhou XH, Xiang X, Wang KY (2009) Evaluation of oregano essential oil (Origanum heracleoticum L.) on growth, antioxidant effect and resistance against Aeromonas hydrophila in channel catfish (Ictalurus punctatus). Aquaculture, 292(3-4):214-218.

\section{Figures}
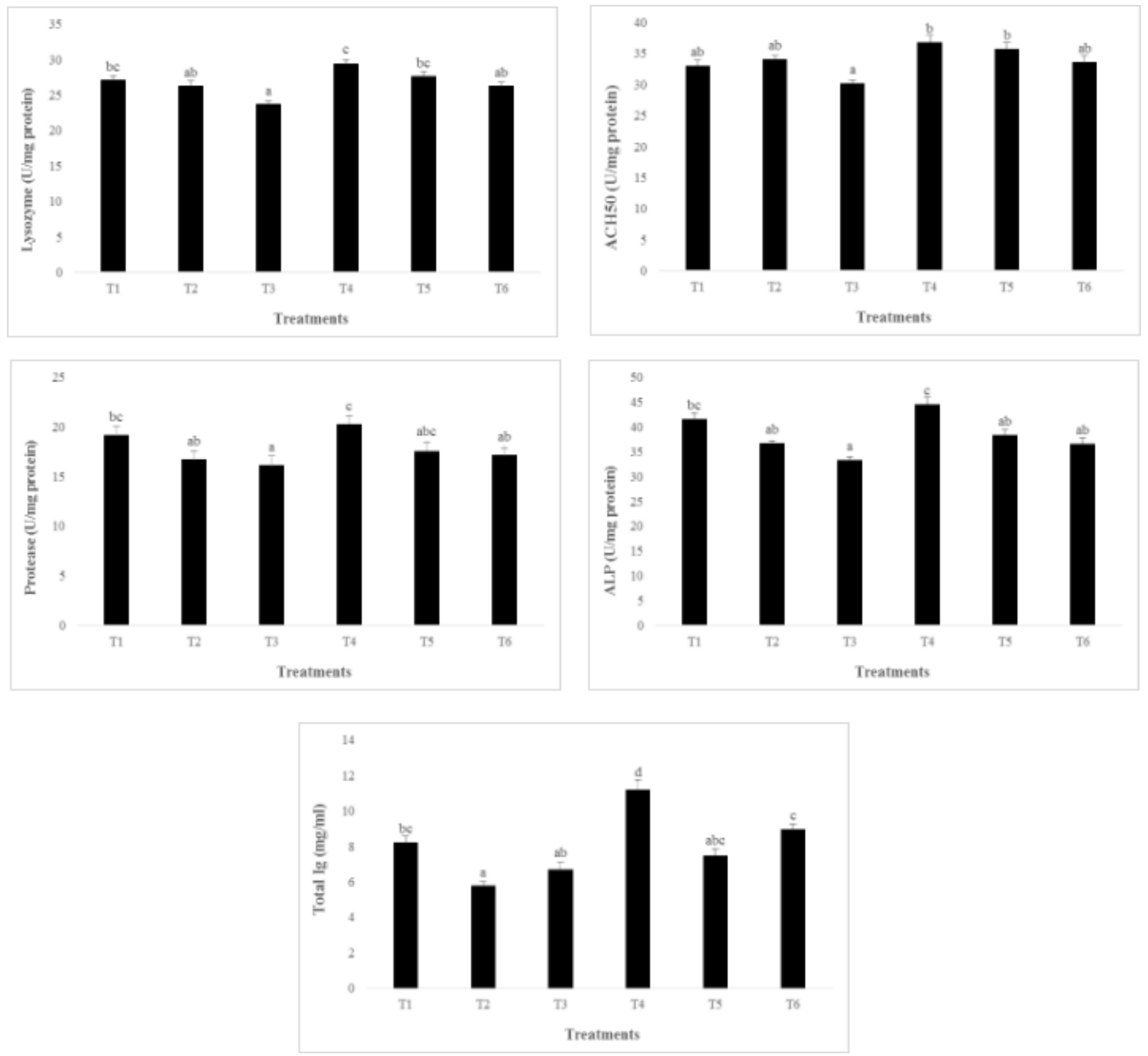

Figure 1

Effect of dietary supplementation with Satureja hortensis and/or exposure to sub-lethal Pretilachlor toxicity (1/2 and 1/4 $\left.\mathrm{LC}_{50} ; \mathrm{mg} / \mathrm{I}\right)$ for 21 days on the mucus Immunological indices (lysozyme activity, alternative complement activity $\left(\mathrm{ACH}_{50}\right)$, Protease, total immunoglobulin levels (Total Ig), protease, alkaline phosphatase (ALP)) of Cyprinus carpio. 